\title{
Cross-Border Mobility between South Africa and Zimbabwe: Historical and Contemporary Trajectories of Development in Musina, South Africa
}

\author{
Joseph Rudigi Rukema*, Nedson Pophiwa \\ University of KwaZulu-Natal, Durban, South Africa \\ ${ }^{*}$ Corresponding author: School of Social Sciences, University of KwaZulu- \\ Natal; email: josephr1@ukzn.ac.za or jrukema@yahoo.com
}

This paper explores and investigates the historical context of cross-border mobility across the Zimbabwe-South Africa border into Musina, especially with respect to the changing economic conditions in Musina and the surrounding areas. It shows how the ZimbabweSouth Africa border has evolved over time since its demarcation in the late nineteenth century and how its meanings have changed during different time epochs. The colonial regime was for the most part interested in obtaining cheap labor from the region and so mobility of African immigrants was not restricted except where the different employer groups pressured the state to control such movements. More recent forms of mobility include short-term movements for cross-border shopping and recreation, but also a massive influx of migrants and refugees from Zimbabwe that has overwhelmed the local job market. The resulting strain on the resources of the local community has resulted in calls for tighter control of such movements.

Keywords: Border studies, Labor migration, South Africa, Zimbabwe, History

The main aim of this paper is to place cross-border mobility across the Zimbabwe-South Africa border into Musina into historical context, in order to gain an understanding of changes that have occurred over time and how they influence contemporary dynamics in the town. It demonstrates that there is a long history of cross-border mobility between South Africa and Zimbabwe since the pre-colonial period. During the colonial period when the South Africa-Zimbabwe 
border was demarcated, labour migration to South African mines became the leading kind of mobility across the border. As a result of rapid socio-economic change in the last two decades, 'new mobilities' have emerged following the decline in mining-driven labor migration. Among these new mobilities is crossborder shopping by Zimbabweans which had not been a prominent activity from the formation of the town in the early 1900s until only a few decades ago. The increased presence of Zimbabweans in Musina witnessed increased mobility for different purposes, namely, (i) for settlement (whether temporary or permanent) in the town, (ii) transit to other urban destinations in the country, and (iii) mobility for the purposes of consumption of goods and services in the town.

As succinctly captured in the opening quote by Morreira (2013), an avid observer of daily life in Musina's city center will notice people, goods, and vehicles in motion. Almost on every corner items are being exchanged, people converse in Venda, Shona or Ndebele, while trucks are loaded with goods destined for Zimbabwe. All this hustle and bustle only occurs during shopping hours and once the shops close around 5pm, quiet is restored to the town. Because they use the N1 highway to access the town, the road has been nicknamed after the Zimbabwean president. Mahati (2015:18) writes:

Such was the huge presence of Zimbabwean shoppers with very few South African registered vehicles along one busy street in Musina that one senior local authority official commented that it was commonly called "Robert Mugabe Street", after the President of Zimbabwe. Anecdotes have it that the street was named after Robert Mugabe as it is heavily populated by Zimbabweans and he is widely accused by his critics of causing such a presence of Zimbabweans in Musina.

Zimbabweans are engaged in informal economic activities in the urban confines of Musina as informal cross-border traders, cross-border shoppers, transport operators and doing other forms of border work which involves charging fees for facilitating movement of goods and people across the border.

Further away from the town are the border farms where a number of Zimbabweans engage in formal employment either as permanent or seasonal workers. There is a plethora of scholarship which shows how in the past few decades the border farms have become important employers for Zimbabweans (Addison, 2014; Bolt, 2013, 2014, 2016; Rutherford, 2011a,b). Bolt (2016:68) concurs that "cross-border mobility, ineffective state attempts to control its boundaries, and local capitalism with relevant workforces have all shaped the area over a long period." Therefore, these dynamics need to be understood in terms of a wider history. It must be noted however that due to scarcity of sources, especially those that focus on activities such as shopping and trade, it is difficult 
to provide a detailed historical account of certain events that occurred in the town. The archival material in the National Archives of South Africa is awash with files on the Messina Transvaal Development Company (MTDC) and labour migration by citizens from colonial Zimbabwe and other parts of the region since the 1900 s. Before delving into these historical accounts, the following subsection discusses contemporary Musina.

\section{Overview of Musina}

Present-day Musina (previously referred to as Messina until 20021) was established in 1904 on a farm called Berkenrode following the setting up of mining activities on the same property. A British Lieutenant Colonel John Pascoe Grenfell is said to have obtained a discoverer's certificate in order to mine copper (Bolt, 2016:79). Grenfell knew of copper mining activities by Africans in that area, so he set out to begin large-scale mining. Under the proprietorship of the MTDC, Grenfell would change the economic history of the region with his mine, which attracted labor from different parts of Southern Africa. It was much later, in 1957, that Messina was proclaimed a town, establishing its own municipality (Raper, 2004:238). Following the advent of democracy in 1994/1995, the Local Authority Committee for Nancefield and the Town Council of Messina were amalgamated and became the Greater Messina Transitional Local Council, and after the election in December 2000 the municipality was established as the Messina Local Municipality.

According to the Census of 2011 Musina's population stood at 68,359, a significant increase from a total of 39,310 in 2001.2 Even though the Musina Copper Mine was shut down in the late 1980s, mining still contributes significantly to the local economy. Since 1992, the De Beers owned Venetia Diamond Mine, located about $90 \mathrm{~km}$ from the town, became operational. Agriculture is also a critical sector. The border farms, as will be explained, play a critical role for territorial control and they employ thousands of migrants. Musina's economy is based on agriculture, forestry and fishing (30\%), mining (20\%), transport and communication (10\%), manufacturing $(9 \%)$, finance and business services $(9 \%)$, wholesale and retail trade, catering and accommodation (6\%), community, social, personal services $(6 \%)$, government services $(5 \%)$, and construction $(5 \%)$ (Musina Local Municipality, 2012). Residents of villages surrounding Musina frequently visit the town for shopping or in search for opportunities to work in the

1 The spelling of the name was changed to Musina in 2003 to correct the colonial-era misspelling of the name of the Musina people.

2 Cited in 2016/17-2021 Consolidated Integrated Development Plan. 
mines or on farms in the area. These rural places include Mudimbo, Bale, Mutale, Gundo, Malale, Pfolovhodwe, Nzhelele and others. As a local government entity, Musina Municipality's administrative area is characterized by a relatively equal urban-rural population split.

We posit that Musina has gained much in importance since the apartheid years. In the apartheid era, Musina was a mining town that offered employment opportunities to Africans from neighboring countries and served as a transit zone for labor migrants destined for more lucrative employment on the Witwatersrand. However, the town was not more dependent on the border post than expected of border towns until the post-2000 period. What makes Musina a border town as the concept is applied in border studies? According to Buursink (2001:7), a border city/town "is a place more or less dependent on the border for its existence.... it is not just a city located close to a border, but it also came into existence because of the border." Economically, typical border cities tend to be less prosperous and less developed than the core regions (ibid.). In other instances border towns are characterized by inequalities of wealth and power within the country and beyond the border, for example, the US-Mexico border and along the borders between South Africa and its neighbors, where towns stand as "symbols for other kinds of unequal relationships" (Nugent, 2012:557). Musina has over the years become an important border town not only for cross-border shoppers and traders from Zimbabwe, but from Zambia, Malawi and Mozambique as well. As this paper will show, the town diversified from its earlier function during its formative years as a mining town to become a retail and wholesale hub for the region. The town has increasingly become dependent on the border for its present existence, as Buursink (2001:8) says of border towns elsewhere which are isolated from their hinterland.

Musina has been gaining recognition over the years owing to its strategic location as "a gateway to Africa". In recognition of the importance of operating as a border region the town was designated by the Department of Trade and Industry in 2013 as a Provincial Growth Point and declared a Special Economic Zone (SEZ) (1 ${ }^{\text {st }}$ order settlement) due to the relatively high level of economic activity and rendering of services to local and surrounding communities. ${ }^{3}$ There are

3 The corridor is envisaged to run from Makhado through Musina and ending at Beitbridge on the border with Zimbabwe. This corridor is endowed with large reserves of minerals and is one of the agriculturally rich areas of South Africa, with great potential for manufacturing industries. It aims to attract investors to grow in a manner that creates sustainable jobs, and ultimately improve the living conditions of the people. This MUTASSHI/Musina Corridor Development Initiative is seen as part of the Limpopo Growth and Development Initiative. 
proposals linked to the SEZ, such as MUTASSHI (Musina to Africa Strategic Supply Hub Initiative) and Limpopo Eco-Industrial Park (LEIP) initiatives which will turn the town into an industrial and logistics hub (Department of Water Affairs, 2014). Before explaining contemporary patterns of cross-border mobility in Musina from Zimbabwe, the following discussion will provide a brief history of the border and the town.

\section{A synoptic history of the Zimbabwe-South Africa border}

What became officially known as the South Africa/ Southern Rhodesia border was established by the Pretoria Convention concluded between the United Kingdom and the Transvaal on the $3^{\text {rd }}$ of August, 1881 (Ndlovu, 2012). This convention officially declared the border would be demarcated by the Limpopo River which had served as a natural 'boundary' between Transvaal and Matabeleland stretching through to the confluence of the Luvhuvhu River (Pafuri) (ibid.). A follow-up convention in 1884 between the British High Commission in South Africa and the Governor of Good Hope and delegates from the Transvaal restated the same Limpopo boundary (ibid.). On the Southern Rhodesian side, following the defeat of the Ndebele forces in 1894, the British government issued what was called the Matabele Order-in-Council, which officially recognized the present-day boundaries of Zimbabwe (Musoni, 2012). Several decades later in 1957, through successive negotiations and deliberations with its neighbor, the Secretary for External Affairs of the Union of South Africa and his counterpart, the British High Commissioner for the Federation of Rhodesia and Nyasaland, agreed that their common boundary was the median of the Limpopo (ibid.). Prior to the pronouncement of the Limpopo as the official border line in 1881, movements between the territories can be referred to as "cross-Limpopo River mobility" (see Musoni, 2012). The result of the new colonial boundary between the two territories was that for the first time ever, activities across the Limpopo River would be subjected to restrictions and controls by the two colonial governments. The rise of the migrant labor regime, which supplied the human resources needs of farmers, mine owners and other employers in both South Africa and Southern Rhodesia, meant that previous forms of cross-Limpopo activities, such as hunting and trade exchanges, became less significant (ibid.).

The Limpopo Valley was sparsely populated by white settlers. It is estimated that over $90 \%$ of Southern Africa's cattle were wiped out by the devastating rinderpest outbreak between 1896 and 1897(Bolt, 2011:96). Land ownership was largely characterized by absentee ownership, and land speculation was rife. The state was "practically non-existent" at that time (ibid.). Gradually with time, control of the movement and recruitment of African migrants became a prerogative of the 
state officials - a task they had to juggle with other pressing mandates such as meeting the needs of capitalists and the imperial demands to determine who did or did not qualify to live in the colonial state (ibid.:97). It was only when the Beit Bridge (named after Alfred Beit) was opened in 1929 that a dedicated control post was opened (Macdonald, 2012). Before that time, Transvaal patrollers and their Rhodesian counterparts had shared responsibilities of controlling movement across the border. Such a task had never been easy considering the technical limitations of the state officials to effectively monitor, control and restrict unauthorized entry or exit across the Limpopo River. Also the competition for labor among employers on both sides of the border made it difficult for officials to curb unauthorized movements regardless of existing legislation. African agency is also critical in this regard because migrant laborers from as far afield as Nyasaland (present-day Malawi) trekked to work on the Rand or on South African farms instead of working on Southern Rhodesian mines or farms.

In the late 1970s the apartheid state realized the importance of boosting capacity in regulating movement across the border. Whenever rumors of anticolonial uprisings occurred "with uncanny similarity all along South Africa's international borderlands" (Macdonald, 2012), the apartheid state moved in to quell them. This is when the apartheid state decided to lure farmers to the area around Messina which bordered with Rhodesia so as to participate in the local commando. Since the rise of insurgencies, particularly Umkhonto we Sizwe, a decision was taken to bolster security around the periphery, thus:

On the Zimbabwean border a 'no man's land' was established between the two countries consisting of two lines of barbed wire fences with a clear track for army patrols. During the 1980s sisal was planted in between the fences and west of Musina the fence was electrified. The African National Congress (ANC) armed wing, Umkhonto we Sizwe (or MK) (translated 'Spear of the Nation'), placed landmines on white border farms, labelling such places as legitimate military targets (Derman \& Kaarhus, 2013:147).

White farmers were brought to the area precisely to enhance the state's capacity - which culminated in an agricultural area that would gain prominence in the post-apartheid era.

\section{Messina: Mining, labor and retail activities}

An important episode in the bordering process of the South Africa - Southern Rhodesia border was the formation of Messina copper mine in 1904 by John Pascoe Grenfell. The mine, according to Bolt (2011:99), "tamed the Transvaal's northern frontier, and became an economic hub in the Limpopo Valley". There 
had been mining of copper in pre-colonial times, but this had ceased when BaVenda and BaSotho scattered the Musina community (ibid.). For the Union of South Africa authorities, Messina was just an area in which to police immigration and not a place to settle. Nonetheless the mine management authorities played a crucial role in ensuring that infrastructural development in the area was instituted through railway construction and a road link with Pietersburg, as well as other amenities like a hospital, a recreation club, and others. In later years the mine's importance was acknowledged in an official communique written in the 1930s which read in part:

In March, 1933, 224 Europeans were employed by the Company and of these $78.8 \%$ were South African born. The number of Europeans directly dependent on the mine for their livelihood can be set down at 1000 in round figures. There are good grounds for the company's claim that its operations have indirectly benefited the Zoutpansberg district to a very great extent. It has up to now played a big part in the economic life of the Northern Transvaal and the village of Messina, which is practically dependent on the continued activities of the Mine, provides the only market for a large area (NTS 2077 178/280).

For many years the mine management continued to lobby the state for recognition and support especially in the area of labor recruitment where they faced competition from other parts of the Union.

The mine management struggled to gain a consistent supply of labor owing to competition with the Witwatersrand where most African migrant labor preferred to work. In many instances the Messina Mine authorities petitioned the Director of Native Affairs seeking assistance with ensuring that labor was secured by discouraging or putting an end to the activities of recruiters who stole laborers right under the company's nose. During the 1940s, the mine owners were joined by the commercial farmers emerging in the area especially in Njelele, who also required labor but often lost it to recruiters who channeled labor to more lucrative farms in the interior (Bolt, 2011:110). They also expressed concern at the employment of foreign migrant labor when the locals were being excluded:

It has come to the notice of this Department that out of 3000 Natives employed on the Messina Mine only about 500 are Union Natives. In view of the wide-spread unemployment amongst Union Natives your assistance in securing preference in employment for local Natives would be appreciated. The Department is given to understand that the Bavenda like and desire work on the mine and the full labor complement of your Company could be supplied from local sources. The Native Commissioner 
at Louis Trichardt and the Assistant Native Commissioner at Sibasa will willingly co-operate with mine officials in making your labor requirements known to Natives in their areas (NTS 2077 178/280).

According to Malunga (2002:285), "the locals, not only at Messina, but also at other mining and industrial centres in the Union of South Africa, blamed the foreign migrant for their unemployment. In 1928 this attitude manifested itself when the Transvaal African Congress, spearheaded by Selby Msimang, pressed delegates to apply political pressure on government to deport all Nyasas, arguing that these men who often worked as mineworkers or domestic servants, deprived local men and women of employment opportunities."

On the other side of the border, the administration of Southern Rhodesia became fully aware of the exodus of its experienced mine labor force to Messina. So on one occasion they requested the Union of South Africa to visit the mine and see what drew its people there. They sent a government representative by the name of W.E. Thomas. According to an account cited by Malunga:

The Southern Rhodesian representative found that the average rate of pay for Messina underground mineworkers was 40s. a month compared to $15 \mathrm{~s}$. a month in his country. He also found that although the Messina Company was not declared a labour area, the mine adhered to the Transvaal Food Ration Regulations. The officer also reported that everything necessary for the well-being of Rhodesian mineworkers was provided for at the Native Mine Hospital. In the opinion of Thomas, better wages, better food rations and better living conditions in the compounds were the pull factors for the Rhodesian mineworkers to Messina (Malunga, 2002:284).

This account demonstrates that the asymmetrical relationship between Musina and the Union of South Africa was developing already in the early 1900s, right from the formative years of colonial rule. The areas from where clandestine labor migrants came were the southern parts of South Rhodesia. According to Malunga (2002:18):

Between 1930 and 1950 even those Rhodesians, who were domiciled in the rural areas along the South African-Rhodesian border flocked to Messina to seek employment. Uppermost in the minds of these people was the desire to raise enough funds to buy livestock back at home. Because the majority had no experience of underground mine work, they were employed for surface work in the smelter division, at the pump station, rock sorting and some as messengers. 
This pattern of mobility by residents from southern parts of Zimbabwe to Musina is still occurring today. The majority of Zimbabwean immigrants working on the farms at the border post originate from these proximal zones of southern Zimbabwe.

Prior to 1966, when the Witwatersrand Native Labour Association (WENELA)'s right to recruit in South Rhodesia was legally barred, the Messina mining company remained the single largest employer of Southern Rhodesia mineworkers in the Union (Malunga, 2002:284). Even though colonial authorities tried to control African jobseekers' choice of where to sell their labor, they never succeeded in doing so. Legislation was often ignored and practices on the ground were against the law. African migrants exercised agency in making choices of where to sell their labor:

Despite calls for restriction from many quarters, officials continued to struggle with the immense challenges presented by vast borderlands, by sophisticated networks of intra-continental migration and by the continued clamour of industrial and agricultural constituencies for cheap foreign labour (MacDonald, 2012:245)

Chaotic incapacity and strategic permissiveness proved to be durable limits on coercive border making, despite the creation of dedicated immigration restriction infrastructure (MacDonald, 2012:41). Illegal border crossing was perpetuated by the courage of transport schemes operating between Messina and South Rhodesia. According to MacDonald (2012:257), there were lorries which plied the Gwanda to Beit Bridge route six times a week ferrying African immigrants seeking employment in Messina. He states that these men were not easy to stop even if police could do so because they were fearful that the drivers "will ride over anyone attempting to hold them up" (MacDonald, 2012:257). Behind these transport schemes at times were the borderland farmers who would send out runners, touts and drivers to numerous small border towns in the Northern Transvaal as well as beyond the borders. The immigrants themselves knew when to cross the Limpopo River. Particularly during winter when the river was at its lowest, they found ways to skip the Union border (ibid.). Indeed there is a long history of clandestine movements across the border which resonates with patterns of recent years.

\section{The development of retail and other infrastructures in Messina}

A pamphlet by Mills (1952) titled Messina Northern Transvaal: A Short History provides a synoptic history of early life in Messina following the formation of the mine. The author observed that by 1905 the mine was fully operational and the early residents of the area erected partly-built mud huts, cleared away the 
bush, and where necessary hunted lions and other wildlife. According to Mills (1952:10), the living conditions were very backward:

Most of the single men lived in little home-made shacks of logs or canvas, or anything which could be found. These shacks were scattered all round the mine and were very primitive, with no sanitation and only a water tap nearby for washing. Each little kia had a straight, well-worn path to the pub, and each path was lined with empty bottles.

Road infrastructure at the time was still non-existent, which meant that when it rained their wagons were stuck in mud and in dry weather they had difficulty in the sand. Nevertheless the home-made shack soon gave way to brick buildings, the bush was cut back, good water discovered and arrangements made to bring in fruit, eggs and fowls (ibid.:11).

Mills further observed that traders were not long in the following when The Limpopo Trading Store and Messina Hotel opened their doors in 1906. The Limpopo Store was a collection of small mud buildings, while the Hotel at this time had a "brick front with corrugated iron lean-to buildings which did duty as rooms" (ibid.:12). A branch of the National Bank (which later became Barclays Bank) was opened in 1913. The same account describes who we can say were the first cross-border shoppers since the demarcation of the international border:

In the meantime, Police camps had been established at Messina and by the BSA [British South Africa] police on the other side of the river. The Rhodesians used to come across the river on camels to do their shopping in Messina. Meat supplies arrived once a week by coach, but vegetables were a rarity (ibid.).

It is interesting that camels were used during those years as modes of transport. We could not establish what ever became of those camels and when they ceased to exist as a mode of transport. ${ }^{4}$ For several decades the Limpopo Store was an important shop in the town where many obtained their supplies. During the apartheid era black and white shoppers used separate entrances/exits and were served at different counters. One interviewee recalled:

You know even when I grew up in the 1980s we used to buy bread, milk and other groceries at the counter at the back of the shop separate from the whites. It was regarded normal like that even though the prices for the

4 One of the photographs on the walls of Mr Jack Klaff's boardroom shows BSA police on camels making a stopover at Limpopo Store to buy. 
goods were the same. You could also buy furniture and other hardware items there. (Musina resident, male, 57)

Although the shop was closed down (none of my respondents could tell when), the former Limpopo Store remains in present day Musina with a bank (Capitec) and Kentucky Fried Chicken as new tenants. In our interview with a former mayor of the town, he summarized the major developments in the town in this way:

This was originally a copper mining area under MTDC up to the late 1980s when it was closed down. Farms on the border with Zimbabwe began to receive more government assistance to stimulate farming in the 1980s as well as to safeguard the border which was under attack by the ANC when it set up landmines in the area. It was during the same time right about the early 90s that De Beer then came into the area and started prospecting for diamonds, which then led to the formation of Venetia Mine. This mine made a big difference to the community as a new residential area was contributed and additional infrastructure thus bringing back life into the town. A few years later the whole area became open to the rest of the continent and the border post was no longer heavily regulated (J. Klaff, retired mayor of Messina, 8 July 2018).

From there he saw the town expand to the present extent as new retail developments sprang up in the central business district.

\section{Increased presence of Zimbabweans and rapid socio-economic change after $\mathbf{2 0 0 0}$}

The increased presence of Zimbabwean citizens has led to mixed outcomes for the border town. We deduced from a couple of interviews in Musina that in general, Zimbabweans are viewed as a burden on Musina. Although it is a transit zone, Musina is also a destination. In some of the conversations with locals, a sentiment was expressed that the town used to be 'cleaner' in the past than now because of all these populations coming in from the other side. This same sentiment was reinforced by an interviewee who guards one of the entrances to a bus terminal in the town:

We used to even have days on school holidays when we would come together in Nancefield as school children, then we would sweep the streets and pick litter. At the end of the day we would be given refreshments and snacks. It was nice in those days. Now the town is just too dirty. (Mudau, 36, local resident, Musina) 
While such sentiments are rife in locals' ways of imagining the 'better past', which ironically was the apartheid times, one point they miss is that even with a growth in population, the local municipality can still maintain a 'clean' town. The poor standards of cleanliness in the town can also be attributed to inefficient service delivery on the part of the municipality, but Zimbabweans are blamed instead for the filth in the central business district of Musina. In Nancefield, one man was interviewed who also mentioned that anything Zimbabwean is regarded as bad to such an extent that local mothers discipline their kids by threatening that they will deport them to Zimbabwe for misbehaving. The images which these children have of Zimbabweans are those of desperate people from that country whom they encounter in their daily lives. None of them wants to be like those Zimbabweans.

One can argue that 2008 was the year when Zimbabweans began to be viewed and labelled a 'burden' on Musina. Rutherford (2011a:220) observed the marked changes that were occurring in the town:

The situation of Zimbabweans in Musina changed significantly since the middle of 2008. Before then, there were many people of Zimbabwean origin living in Musina but most of them came before 2000, if not before the end of apartheid. They came as workers in the copper mine in Musina or on mines surrounding the border town, or as border traders, or came to live with relatives and made their lives in South Africa. Before 2008, however, there were not too many recently arrived Zimbabweans who had openly moved about. There were many who worked in town, but they generally kept hidden in fear of being deported.

At this point in the history of Zimbabwean mobility in Musina, one could see how this population group had for several years tried to remain 'hidden' from police in fear of deportation. However, fleeing political violence and starvation from economic collapse, and some in search of treatment for cholera, Zimbabweans appealed to South African state authorities for essential services.

Following a disputed election in March 2008, economic collapse in Zimbabwe reached unprecedented levels as hyperinflation eroded citizens' incomes severely. Food shortages were still widespread and as the ruling ZANU-PF party called for an electoral run-off, more violence erupted. Musina became host to a significant population of Zimbabweans, most of whom were fleeing these tough economic times and also political persecution. The mix of mobile populations in Musina, with unaccompanied children, women, youth and men, was so diverse that the South African government was taken by surprise. The existing policy framework of deporting undocumented migrants was rendered obsolete and too costly because the numbers were too large. One report by a humanitarian 
organization captured the plight of Zimbabweans in Musina in February 2009 as follows:

There is a developing humanitarian crisis involving the living conditions of Zimbabwean nationals in Musina, South Africa. The border town of Musina is the first stop in South Africa for many of those who fled political persecution or the dire socio-economic conditions in Zimbabwe in search of protection and a means of meeting basic survival needs. Yet on arrival in South Africa, many are faced with renewed threats to their rights due to delays in the provision of legal documentation, the lack of humanitarian service provision, illegal procedures being undertaken by local authorities and exploitation of the vulnerabilities of Zimbabwean nationals by a variety of actors (Chiguvare, 2011).

The same report mentioned that at the time about 3,000 to 4,000 Zimbabwean nationals were sleeping in an unpaved parking area at Musina Showgrounds where they applied for legal status from the Department of Home Affairs (DHA).

In response, DHA set up a Refugee Reception Centre in July 2008 where asylum seekers could apply for a seekers' permit, which allowed them to work while waiting to be granted refugee status. ${ }^{5}$ The DHA rented the local municipal show grounds in order to register undocumented Zimbabweans using Section 22 of Immigration Act 2002 and legalize their stay in the country (Derman \& Kaarhus, 2013:161). This arrangement ran from July 2008 to April 2009 when the DHA ordered the closure of the Showgrounds without an alternative plan for the refugees. During the period of its operation the South African government prohibited the construction of "permanent structures" such as tents, portable toilets, or creating a formal refugee camp because "they believed such a facility would attract additional Zimbabweans to the country" (Fritsch et al., 2010:631). The conditions at the showgrounds were deplorable and were regularly lambasted by humanitarian organizations operating in the town.

Aside from the DHA temporary refugee reception center, another important response to the Zimbabwean crisis during those years was the opening up of shelters belonging to humanitarian institutions which attended to humanitarian needs of Zimbabweans in the town early in 2009. Organizations such as Save the Children - United Kingdom and Doctors Without Borders were critical in attending to the humanitarian needs of Zimbabwean 'refugees' who were crossing daily into Musina. The shelters around Musina did not only serve the

5 Prior to this the next Refugee Reception Centre was in Pretoria close to $500 \mathrm{~km}$ away. 
purpose of providing food and accommodation for their occupants. Some of the occupants of these shelters obtained a livelihood by selling food and other essentials to their fellow countrymen. The same sites were also places for labor recruiting. Local farmers would visit the shelters to recruit men and women who were willing to work on their farms. At women's shelters, local South African residents in Nancefield would source for domestic maids to clean and do laundry for them. Because the Zimbabweans were many in numbers they often would bid downwards their wages when an employer asked them how much they wanted to be paid (Rutherford, 2011a:224).

Another noteworthy response to the neighbor's crisis was that early in 2009 deportations of undocumented Zimbabweans in South Africa ceased after the host country realized the wasteful nature of mass deportations. These policy shifts later paved the way for the Zimbabwe Documentation Project which provided work, study and business permits for four year periods to about 250,000 who had applied (Derman \& Kaarhus, 2013:161). Thus the announcement that DHA would halt deportations of Zimbabweans "completely changed the social geography for Zimbabweans in Musina, as elsewhere in South Africa" (Rutherford, 2011a:221).

In the same year 2008 a nationwide cholera outbreak in Zimbabwe resulted in a considerable number crossing the border in search for treatment. The total number of cases of cholera as of 23 March 2009 was 92,432 cases with 4,072 deaths (Mason, 2009:151), a figure which surpassed the World Health Organisation's worst-case scenario (Nelson, 2009:15). This became a serious humanitarian crisis overnight. The country's public health system had collapsed completely during the time of hyperinflation. So images of hundreds of Zimbabweans seeking treatment at Musina hospital on a daily basis were interpreted as evidence that "Mugabe had allowed his country's health, water and sanitation infrastructure to collapse" (Tempelhoff, 2009:176). Because of its central location in the town, Musina hospital was conspicuous as a site where Zimbabweans sought medical attention in tents pitched on the grounds of the hospital. This certainly caught the attention of locals who expressed empathy at first but as time went on, some began to view these refugees as a burden on resources. Take for instance this account which shows that the growing population of Zimbabweans in need of humanitarian assistance was fast becoming a burden on local residents at the time:

Local business people, who at first provided assistance and gave the refugees food and water, now became irritated by their presence. They were tired of constantly giving food to those who appeared to be ungrateful for the help they received. Public facilities, such as toilets, parking spaces 
and parks became crowded and locals complained of a deterioration of their quality of life (Tempelhoff, 2009:180).

It is reported that by the end of November 2008 about 650 cases of cholera were reported in the town seeking medical help at the hospital. The widely held view of Zimbabwe as the only culprit spreading the disease began to change as more reports of cholera in other parts of South Africa began to emerge. The narrative began to focus on other local reasons for the spread.

Another category of mobile populations entering Musina during the time of heightened crisis were unaccompanied minors or children, "most of whom had their minds fixed on getting a job in South Africa" (Mahati 2015:141). In August 2008, a Child Protection Rapid Assessment was carried out in the Musina municipality. The assessment concluded that more than 600 unaccompanied children were living in the town of Musina (Swart 2009:110). These children presented a challenge for humanitarian organizations whose interventionist approaches were modelled on the principles that these were children who needed protection and not employment. However, many of the children were in fact "independent" in their thinking and had exercised agency by crossing the border into Musina with intentions to work and support their siblings back home. They also had come to South Africa with perceptions that life in the country was easy, jobs were readily available, and there was access to free education. Most of these expectations were not met (Chiguvare, 2010:20). In his thesis, Mahati (2015:141) observed that the children worked in all sorts of occupations just to eke out a living:

A significant population of independent children, including those attending school, were doing or seeking menial jobs. Independent children with no work permits worked as porters, farm workers, collectors and sellers of shopping receipts with Value Added Tax (VAT), which could be claimed by non-resident travellers when they leave South Africa, hunters of wild animals like warthogs, beggars, thieves, human smugglers, vendors, collectors and sellers of firewood, domestic workers, car and truck washers, security guards (Some children paid for safe accommodation through guarding spazas at night for no pay), shop assistants, barbers, and hairdressers (Mahati, 2015:141).

Some of the Zimbabwean youth working and living in Musina at the time we conducted this research between 2013 and 2014 explained that they came as young people under 15 years of age. They had now grown and left the shelters in which humanitarian workers wanted them to live while attending school. 
The high levels of migration and movement into Musina by Zimbabweans also brought another challenge for the host town. The Zimbabwe-South Africa border zone became increasingly violent as human smuggling syndicates commonly known as maguma-guma terrorized border crossers. What may have appeared to be a tranquil town was a site where

Every day irregular migrants including children are violently robbed, attacked, threatened and murdered by magumaguma. Magumaguma (in Shona) or amagumaguma (in Ndebele) are mostly male criminals who way-lay undocumented migrants using illegal entry points on both sides of the Limpopo River and violently rob people of their valuables like mobile phones, clothes, and money in Beitbridge and Musina towns. (Mahati, 2015:19)

Musoni (2016:321) argues that "in many ways, maguma-guma's activities are similar to those of unlicensed labour recruiters who operated in the ZimbabweMozambique-South Africa border zone in the early 20th century." This observation he makes in light of the reports which emerged in correspondence by Southern Rhodesia's Chief Native Commissioner in 1916, who had for 13 years "received complaints about 'blackbirders', who deployed violent methods of recruiting people in the border districts for work in South Africa." The same report went further to mention that "these men have been terrorising all the natives in the districts by flogging them and threatening to shoot them, the natives are afraid to stay in their kraals on account of these men."

\section{Zimbabwean labor and commercial agriculture along the border}

The last form of mobility across the Zimbabwe - South Africa border in the post-2000 era which we will discuss is farm labor. At the time of crisis in Zimbabwe, there was relative growth and expansion of farming along the border. It is therefore incomplete for any historiographical account of the Zimbabwe South Africa border not to make reference to these new developments on the border post because they influenced mobility patterns of Zimbabweans crossing into South Africa. In his research on the eastern side of the border, Addison (2013) explains the changing nature of agriculture in Limpopo Province especially among the border farms, where farm management has largely been delegated to other proxies usually white farm managers who come into contact daily with black farm workers. "Delegated despotism", as he calls it, has led to a new production regime which comprises at least four processes namely, a growing casualization of labor, new forms of private and public regulation, the monetization or withdrawal of many previously "in kind" benefits and services for farm laborers, and expansion 
of black intermediaries (Addison, 2013:ii). Zimbabwean migrants find themselves a part of these dynamics as laborers and intermediaries who can be exploited by these capitalist systems.

Informal economic activities were part of the economy of these border farms. Bolt (2014) also shows us how these new farming arrangements come into contact with informality as waged employees supplement their incomes. Employees of these farms engage in informal activities such as selling cigarettes and alcohol on the farms as ways of supplementing their rather meagre incomes. Bolt identifies differences between those who are employed permanently on the farms and their counterparts whose work is seasonal. Seasonal workers do not feel a sense of belonging permanently to the farm so they remit their earnings to Zimbabwe and also are more likely to engage in informal economic activities in the farm compounds. Another group of informal traders who frequent the farms are external traders who come on every payday to sell their wares to the workers. At the end of each month, South African traders come up to the border farms from Musina where they set up markets in the labor compounds and could make as much as R12,000 per month (Bolt, 2014:113). On such days the compounds of the farms are alive with many activities including live bands which come to perform to the workers, binge drinking, and also sexual encounters.

Addison (2014) however cautions against making assumptions that the crisis in Zimbabwe and migration to South Africa have been engineered by South African farmers or capital in a larger sense. He says, "the fact that the Zimbabwean crisis and migration to South Africa has escalated precisely at a time when South African agriculture experiences rising demand for casual workers suggests not a "grand strategy" on the part of capital and the state, but rather a coincidental intersection of different historical trajectories" (Addison, 2013:32). Bolt succinctly explains that the Zimbabwe - South Africa border farms are the sites where "the dynamics of globalised export agriculture intersect with the fallout of the Zimbabwean crisis" (Bolt, 2016:562). This coincidence which the two authors allude to does not apply to the arrival of Asian retailers in the border town, most of whom told me that their major purpose for coming into the town was to tap into the Zimbabwean market as a result of shortages during the 2007 period.

The tightening of immigration laws across the Zimbabwe - South Africa borderland impacts negatively on the social lives of border citizens who have kinship ties across the border. In most parts of the African continent border populations can cross freely an international boundary, but since the influx of Zimbabweans in the past decade, there is no special treatment for border residents to cross the border without documentation. In his analysis of how the Venda-speaking people on both the South African and Zimbabwean sides of the 
border conceived the border and what their frequent interactions across the border meant to them, Moyo (2016:430) observed that some of these border residents held identity documents of both countries and used them to their advantage to utilize benefits. He also observed how border crossing is a daily activity for many:

Some Venda-speaking people cross the border in the morning to buy commodities in Messina and travel back to the Zimbabwean side of the border in the evening. Some have become used to the Immigration officials and do not have to present their travel documents. They have to buy the Immigration officials a "drink." For such people traveling to Messina and back to Beitbridge on the Zimbabwean side, this amounts to a shopping trip in the "same community" (Moyo, 2016:435).

Despite official restrictions on cross-border mobility for border residents, they still find creative ways of traversing the border post at any given point in time especially where shopping for daily necessities is involved.

\section{Conclusions}

Since the 1970s historical interest has shifted from 'grand' themes (such as politics, wars etc.) to analyses of past everyday life, privacy, family life etc. We benefited from reading literature on cross-border mobility in examining the nature and extent of mobility in different regions of the world. Reviewing such literature also assisted in situating our study in the discourses on cross-border mobility through historical context. The life histories of cross-border mobility can be conceptualized as expressions of historical events and circumstances which represent a counter history or call into question the official history.

This paper has shown how the Zimbabwe-South Africa border has evolved over time since its demarcation in the late nineteenth century and its meanings during different time epochs. The colonial regime was for the most part interested in obtaining cheap labor from the region and so mobility of African immigrants was not restricted except where the different employer groups pressured the state to control such movements.

The scholarship on cross-border movements across this borderland has also captured the shift from mining-driven labor mobility to other areas of employment such as the farms and informal economy in those spaces as well as in the town center of Musina. These are crucial developments which obtain in other parts of the region as labor migration to the mines has dwindled and migrants have been moving to work in other sectors. What remains as a gap in knowledge is the ways in which daily crossings for purposes of shopping intersect with the retail boom in 
the border town and the South African state's determination to regulate mobility of Zimbabweans.

\section{References}

Addison, L. (2014). Delegated despotism: Frontiers of agrarian labour on a South African border farm. Journal of Agrarian Change 14: 286-304.

Bolt, M. (2011). Rooting production: Life and labour on the settler farms of the Zimbabwean-South African border. Ph.D. thesis, London School of Economics and Political Science.

Bolt, M. (2013). Waged entrepreneurs, policed informality: Work, the regulation of space and the economy of the Zimbabwean - South African border. Africa: Journal of the International African Institute 82: 111-130.

Bolt, M. (2014). The sociality of the wage: Money rhythms, wealth circulation, and the problem with cash on the Zimbabwean - South African border. Journal of the Royal Anthropological Institute (N.S.) 20: 113-130

Bolt, M. (2016). Accidental neoliberalism and the performance of management: Hierarchies in export agriculture on the Zimbabwean - South African border. Journal of Development Studies 52: 561-575.

Buursink, J. (2001). The binational reality of border-crossing cities. GeoJournal 54: 7-19.

Chiguvare, B. (2011). Children crossing borders. An evaluation of state response to children unaccompanied minors at Musina border post, South Africa. M.A. thesis, University of Johannesburg.

Department of Water Affairs (2014). Feasibility study for the MUTASSHI/MUSINA corridor bulk water supply.

Derman, B. \& Kaarhus, R. (eds.) (2013). In the Shadow of a Conflict: Crisis in Zimbabwe and Its Effects in Mozambique, South Africa and Zambia. Harare: Weaver Press.

Fritsch, C., Johnson, E. \& Juska, A. (2010). The plight of Zimbabwean unaccompanied refugee minors in South Africa: A call for comprehensive legislative action. Denver Journal of International Law and Policy 38: 623-658.

MacDonald, A. (2012). Colonial trespassers in the making of South Africa's international borders 1900 to ca. 1950. Ph.D. thesis, St John's College, Cambridge.

Mahati, S. (2015). The representations of childhood and vulnerability: Independent child migrants in humanitarian work. Ph.D. thesis, University of the Witwatersrand.

Malunga, F. (2002). Foreign African migrant labour at the Messina Copper Mines, 19051960. Historia 47(1): 270-290. 
MANKIND QUARTERLY 2020 61:2

Mason, P.R. (2009). Zimbabwe experiences the worst epidemic of cholera in Africa. Journal of Infection in Developing Countries 3(2): 148-151.

Mills, J. (1952). Messina Northern Transvaal: A short history. The Messina Mail-Coach Organising Committee of the Van Riebeeck Festival.

Morreira, S. (2013). Transnational human rights and local moralities: The circulation of rights discourses in Zimbabwe and South Africa. Ph.D. thesis, University of Cape Town.

Moyo, I. (2016). The Beitbridge - Mussina interface: Towards flexible citizenship, sovereignty and territoriality at the border. Journal of Borderlands Studies 31: 427-440.

Musina Local Municipality (2012). Draft Integrated Development Plan: 2012/13-2017

Musoni, F. (2012). With an apron in the caboose: Illegal migration across the Zimbabwe-South Africa border. Ph.D. thesis, Emory University.

Ndlovu, T. (2012). Escaping home: The case of ethnicity and formal education in the migration of Zimbabweans during the Zimbabwean 'crisis'. In: S. Chiumbu \& M. Musemwa (eds.), Crisis! What Crisis? The Multiple Dimensions of the Zimbabwean Crisis, pp. 100-121. Pretoria: HSRC Press.

Nelson, E. (2009). Beyond cholera - the Zimbabwe health crisis. Lancet Infectious Diseases 10: 587-588.

Nugent, P. (2012). Border towns and cities in comparative perspective. In: T. Wilson \& H. Donnan (eds.), A Companion to Border Studies. Oxford: Blackwell.

Raper, P.E. (2004). South African Place Names. Johannesburg: Jonathan Ball.

Rutherford, B. (2011a). The uneasy ties of working and belonging: The changing situation for undocumented Zimbabwean migrants in northern South Africa. Ethnic and Racial Studies 34: 1303-1319.

Rutherford, B. (2011b). The politics of boundaries: The shifting terrain of belonging for Zimbabweans in a South African border zone. African Diaspora 4(2): 207-229

Swart, S. (2009). Unaccompanied minor refugees and the protection of their socioeconomic rights under human rights law. African Human Rights Law Journal 9(1): 103-128.

Tempelhoff, J. (2009). Leaving behind a "twisted soul": The 2008-2009 cholera outbreak in South Africa. Journal of Contemporary History 34(3): 172-189. 